\title{
ANALISIS PEMANFAATAN NEW MEDIA MELALUI JARINGAN MEDIA SOSIAL
}

\author{
Muhammad Khairil \\ Program StudiIlmuKomunikasi, FakultasIlmuSosial dan IlmuPolitik, \\ Universitas Tadulako, Palu, Sulawesi Tengah. Email muh_khairilO2@yahoo.com
}

\begin{abstract}
ABSTRAK
Teknologi berkembang semakin pesat. Dengan diluncurkannya Web 2.0, maka semakin banyak pula media sosial bermunculan dan semakin tinggi pula paparan teknologi. Sehingga pengguna media sosial, sebagai bagian dari Web 2.0 dan new media, juga semakin meningkat pesat. Banyaknya pengguna media sosial ini dimanfaatkan oleh perusahaan-perusahaan sebagai lahan baru untuk mengiklankan dan memasarkan produk-produknya. Media sosial, dan Web 2.0 pada umumnya, selain memiliki aspek positif seperti kemudahan fitur, kencangnya arus informasi dan mudahnya membagikan konten, juga memiliki bahaya dan aspek-aspek negative seperti cyber-bullying, pemalsuan identitas, hacking dan cracking, berbagai macam perangkat lunak yang merugikan (Spyware, Adware, Ransomware, Virus, Malware, dan sebagainya), pembajakan, plagiasi, serta kebocoran dan pencurian informasi. Kemudahan membagikan konten juga membuat komunikator dapat mengemas pesan-pesan dengan simbol-simbol visual tertentu untuk mengirimkan pesan kepada komunikan, yang dalam hal ini adalah pengguna.
\end{abstract}

Kata Kunci: Media Massa, Komunikasi Visual, Pemasaran dan Periklanan

\begin{abstract}
Technology is growing rapidly. With the launch of Web 2.0, more and more social media are emerged and the exposure of technologyisgettinghigher. Social media users, as part of Web 2.0 and new media, are also increasing rapidly. The large number of social media users is used by companies as a new opportunity to advertise and market its products. Social media, and Web 2.0 in general, in addition to having positive aspects such as the ease of features, the tight flow of information and the ease ofcontent distribution, also has the danger and negative aspects such as cyber-bullying, identity fraud, hacking and cracking, harm (Spyware, Adware, Ransomware, Virus, Malware, etc.), piracy, plagiarism, and leakage and information theft. Ease of content sharing also makes communicators can design messages with certain visual symbols to send a message to the communicant, which in this case is the user.
\end{abstract}

Keywords: Mass Media, Visual Communication, MarketingandAdvertising

\section{PENDAHULUAN}

Media komunikasi pada era sekarang merupakan salah satu sumber informasi penting bagi yang sangat berpengaruh masyarakat. Pada umumnya, pola kehidupan individu dalam masyarakat terpengaruhi oleh media yang menjadi sumber informasi yang mendidik, menghibur, hingga memberikan pencerahan dalam interaksi sosial 


\section{National Conference of Creative Industry: \\ Sustainable Tourism Industry for Economic Development}

Universitas BundaMulia, Jakarta, 5-6 September 2018

ISSN No: 2622-7436

individu tersebut, di mana media memberikan gambaran ide tentang individu untuk menilai tingkah lakunya (Kurt, 2015). Dapat dikatakan, media masa masih dijadikan salah satu sumber ilmu dan pengetahuan, serta menjadi perantara dan penyedia informasi, sehingga terkadang media massa berpihak pada suatu kelompok dan atau memusatkan pemberitaan dengan memberikan stereotipe pada kelompok-kelompok tertentu (Ndiayea \& Ndiayea, 2014).

Dalam zaman informasi seperti sekarang ini, komunikator mengemas pesan menggunakan format media audio-visual yang mengaburkan batasan antara seni, teknologi, informasi dan hiburan di tengah-tengah arus informasi yang melaju kencang. Format media audio-visual, terutama aspek visual dari format media tersebut, merangsang kreativitas komunikator dan komunikan dalam mengemas dan memaknai pesan. Dalam hal ini, literasi visual dari komunikan sangat berperan penting dalam memaknai pesan yang dikirim oleh komunikator, karena apabila tingkat literasi visual antara komunikator dan komunikan berbeda jauh, maka akan terjadi ketimpangan dalam penyampaian informasi.

Internet, sebagai bagian dari new media of communication, sekarang berada pada tingkat pemakaian yang lebih tinggi dan variatif (Web 2.0) dibandingkan dengan sebelumnya (Web 1.0). Moda komunikasi menggunakan internet menjadikan arus informasi dunia menjadi seakan tanpa batas, salah satunya dengan melalui media sosial (W. M. Al-Rahmi \& Zeki, 2017). Diperkirakan dari 7,39 miliar penduduk bumi ada 3,4 miliar orang yang memiliki akses internet dan 2,3 miliar orang menggunakan media sosial secara teratur, dan 2 miliar orang mengakses media sosial melalui perangkat seluler yang mereka miliki(Nicolas Alarcón, Urrutia Sepúlveda, Valenzuela-Fernández, \& Gil-Lafuente, 2018).

Media sosial merupakan salah satu contoh penggunaan fitur internet untuk melakukan interaksi sosial dan dapat memberikan dampak positif bagi penggunanya (W. Al-Rahmi, Othman, \& Musa, 2014; Novak, Razzouk, \& Johnson, 2012). Selain untuk kebutuhan interaksi sosial secara umum, media sosial juga dapat dikembangkan menjadi sarana pemenuhan kebutuhan pada tingkat yang lebih spesifik. Salah satu contoh aplikasi media sosial untuk kebutuhan spesifik tersebut adalah implementasi media sosial bisnis (enterprise social media atau ESM) yang berangkat dari kebutuhan untuk mengorganisasi dan meningkatkan loyalitas dari karyawan sebuah perusahaan, serta untuk mengintegrasi, meningkatkan kemampuan serta membangun hubungan sosial bagi karyawan baru (Leidner, Gonzalez, \& Koch, 2018).

Perkembangan era digital seperti sekarang ini juga membuka peluang untuk mengarahkan konten-konten yang dimiliki pengguna ke arah yang spesifik, seperti penyebaran budaya seperti yang telah disebutkan sebelumnya, edukasi, seni dan juga untuk keperluan bisnis seperti transaksi, pemasaran dan iklan. Dengan adanya globalisasi seperti ini juga mengakibatkan terjadinya cultural flows, yang merujuk pada pemindahan objek, kemampuan, kepercayaan dan praktek melalui media dan teknologi komunikasi sebagai bentuk pemerataan budaya dan format media yang ada di dunia (Srivastava, 2008).

Dengan adanya media digital tersebut, pengguna bebas untuk memasukkan konten apapun dikarenakan salah satu sifat media digital, seperti media sosial dan internet pada umumnya, adalah anonim. Sehingga, dalam perkembangannya, diperlukan juga adanya kesadaran pengguna dikarenakan sulitnya menarik konten yang telah tersebar luas pada media internet. Integrasi teknologi pada kehidupan sehari-hari ini pula meningkatkan ekspektasi kemampuan yang diharuskan dimiliki oleh generasi baru, dikarenakan dari 


\section{National Conference of Creative Industry: \\ Sustainable Tourism Industry for Economic Development}

Universitas BundaMulia, Jakarta, 5-6 September 2018

ISSN No: 2622-7436

perspektif literasi teknologi, tingginya paparan teknologi pada generasi baru menimbulkan asumsi bahwa generasi baru pasti memiliki kemampuan dan pengetahuan yang tinggi mengenai teknologi, khususnya teknologi informasi.

\section{New Media Sebagai Media Komunikasi Visual Di Era Baru}

Pada dasarnya, media massa dibagi menjadi dua, yaitu media cetak seperti koran dan majalah; dan elektronik seperti radio, televisi, dan film (Ardianto, Komala, \& Karlinah, 2007). Ada pula media yang dikategorikan sebagai new media yang erat kaitannya dengan media online. Konten new media merupakan gabungan dari data audio dan visual yang dikemas dalam format digital dan disebarluaskan melaui jaringan internet yang berbasis kabel fiber optik, broadband, satelit, maupun sistem gelombang mikro (Flew, 2008).

Media online, sebagai bagian dari new media ofcommunication, tidak terbatas hanya pada media sosial (Levinson, 2009), namun juga termasuk di dalamnya adalah situs-situs yang memungkinkan untuk terjalinnya interaksi seperti Youtube, Blog, Forum, dan lain-lain.

Ketertarikan masyarakat untuk menjadi pengguna new media berdasar pada fiturfitur yang ditawarkan dari new media itu sendiri, salah satunya adalah peningkatan kecepatan arus informasi sebagai dasar dari sebuah interaksi (Nicolas Alarcón et al., 2018).

Komunikasi visual merupakan salah satu bentuk komunikasi yang berfokus pada penggunaan salah satu dari panca indra, yaitu penglihatan. Komunikasi visual tidak terlepas dari proses persepsi visual yang merupakan sebuah proses untuk menentukan pengalaman dan reaksi terhadap stimuli yang dimulai dengan diterimanya stimuli yang menjadi pusat perhatian oleh indra penglihatan audiens sehingga terbentuk pengalaman sensorik yang kemudian dimaknai berdasarkan pengalaman audiens sendiri (Goldstein, 2010).

Aplikasi komunikasi visual pada new media berupa simbol visual digital. Simbol visual digital ini termasuk didalamnya gambar, foto, animasi, tipografi, dan video. Komunikasi visual dalam new media dapat disimpulkan sebagai produk multimedia berdasarkan prinsip proses gambar digital statis dan gambar digital bergerak atau audiovisual (video). Melalui proses ini, komunikator dapat mengemas banyak pesan dalam satu produk visual (Adiloglu, 2011).

\section{METODE PENELITIAN}

Penelitian ini menggunakan pendekatan kualitatif dengan dasar discourse analysis. Data didapatkan dari observasi, studi literatur dan studi dokumen. Data yang terkumpul kemudian dibandingkan satu sama lain dan kemudian dimaknai dan dideskripsikan. Data yang telah dideskripsikan kemudian disajikan dan dianalisis.

\section{HASIL PENELITIAN DAN PEMBAHASAN \\ Media Sosial: Peluang Baru Pada Era Web 2.0}

Web 2.0 merupakan istilah untuk menyebut perkembangan internet pada masa sekarang. Web 2.0 merupakan kumpulan dari konten dan aplikasi yang dikontrol pengguna dan interaktif serta bebas akses (open-source), yang meningkatkan 


\section{National Conference of Creative Industry: \\ Sustainable Tourism Industry for Economic Development}

Universitas BundaMulia, Jakarta, 5-6 September 2018

ISSN No: 2622-7436

pengalaman, ilmu dan pengetahuan yang didapat pengguna. Web 2.0 memungkinkan penciptaan arus ide, informasi, pengetahuan, inovasi dan kreativitas dalam jaringan pengguna dengan memungkinkan penyebaran konten (Constantinides, 2014).

Definisi tersebut berfokus pada pengaplikasian elemen dari web 2.0 itu sendiri. Sedangkan web 2.0 sendiri merupakan hal yang kompleks yang terdiri dari beberapa aspek, seperti teknologi komputer, kemampuan dan pengetahuan sistem informasi, perangkat lunak, dan aplikasi yang terkadang membingungkan dan menimbulkan ambiguitas. Salah satu contohnya adalah penggunaan istilah web 2.0 dan media sosial yang digunakan untuk merujuk satu sama lain, meskipun pada kenyataannya media sosial dan web 2.0 merupakan dua hal yang berbeda (Constantinides, 2014). Mayoritas praktisi mendefinisikan dan menghubungkan media sosial dengan konten pengisi yang dibuat oleh pengguna.

Media sosial dipahami sebagai aplikasi penghubung dengan saluran komunikasi instan dimana pengguna dapat membagikan konten yang diunggahnya. Media sosial tidak hanya terpaku pada satu jenis aplikasi, namun juga mencakup banyak bentuk interaksi dalam jaringan berupa blog, termasuk di dalamnya adalah microblogging; chatroom; forum; situs web, termasuk di dalamnya adalah situs informasi/berita seperti CNN dan The Jakarta Post, hosting/unduhan seperti Mediafire, perdagangan/komersil seperti eBay dan Bukalapak, situs jejaring sosial seperti Facebook dan Myspace, jaringan yang terfokus pada konten video seperti Youtube, dan jaringan yang terfokus pada konten foto seperti Instagram (Nicolas Alarcón et al., 2018).

Pada era digital seperti sekarang ini, tingkat akses pengguna new media semakin meningkat. Pengguna atau masyarakat pun dimudahkan dengan berbagai akses. Sehingga, media sosial menjadi salah satu lahan aktivitas politik, baik bagi pelaku politik maupun pendukung tokoh politik. Dinamika politik dalam media sosial mempengaruhi pola interaksi dalam media sosial dengan terbentuk dan bubarnya komunitas-komunitas pendukung politik atau tokoh tertentu, berdasarkan dengan pihakpihak yang menduduki posisi mayoritas. Dinamika ini juga didasari dari kejadian, ideologi dan ketegangan politik serta afiliasi tokoh dan pihak politik (Weaver et al., 2018).

Banyaknya jumlah pengguna ini dimanfaatkan korporat-korporat sebagai peluang bisnis baru dengan memanfaatkan new media sebagai media pemasaran dan periklanan, dengan menggunakan laman web, video iklan yang disebar melalui laman videohosting seperti Youtube maupun media sosial seperti Facebook dan Instagram. Praktik pemasaran dan periklanan melalui media sosial seperti ini memudahkan untuk membentuk segmentasi konsumen dan persepsi brand dari produk yang dipasarkan (Nicolas Alarcón et al., 2018).

Konsep penggunaan media sosial untuk keperluan pembangunan persepsi brand sangat mempengaruhi pola pemasaran bagi industri atau perusahaan. Banyak perusahaan yang telah menyadari pentingnya menjaga dan mempertahankan media relations melalui media sosial. Kerja sama dengan media-media sosial juga dapat mendongkrak brandawareness suatu perusahaan, dimana melalui kerja sama tersebut, perusahaan dapat menjadi lebih dikenal, contohnya melalui endorsement. Endorsement tersebut juga mempengaruhi dan dipengaruhi oleh brand, pelayanan, dan kredibilitas kedua belah pihak (Varghese \& Rahman, 2014).

Media sosial juga mendukung kapitalisasi informasi dengan penyebaran informasi perusahaan dengan mudah serta mempermudah perolehan informasi mengenai karyawan, penyuplai dan klien dalam jumlah besar. Informasi-informasi ini dapat 


\section{National Conference of Creative Industry: \\ Sustainable Tourism Industry for Economic Development}

Universitas BundaMulia, Jakarta, 5-6 September 2018

ISSN No: 2622-7436

berupa informasi-informasi krusial yang dapat membantu stakeholder untuk menentukan kemana arah perkembangan perusahaan (Georgescu \& Popescul, 2015). Hal ini dikarenakan perekonomian tidak lagi hanya bergantung pada sumber daya alam saja, namun sedikit demi sedikit mulai dipengaruhi oleh sumber daya intelektual dan sumber daya digital. Dengan adanya pergeseran sumber informasi ke arah digital seperti ini, memungkinkan evaluasi kondisi perusahaan dengan lebih mudah. Perusahaan juga bisa lebih mudah membangun relasi dengan konsumen melalui interaksi yang dibangun melalui media sosial (Elena, 2016).

Kenyamanan, kemudahan dan kecepatan lingkungan media sosial menjadikan pengguna cenderung terlalu sering menggunakan media sosial sehingga terkadang sering mengabaikan bahaya dan aspek-aspek negatif sebagai dampak penggunaan media sosial yang terlalu berlebihan. Ketertarikan pengguna terhadap media sosial berakar dari kemudahan mengumpulkan informasi dibandingkan dengan kehidupan nyata, namun lingkungan digital ini juga memiliki permasalahan sosial, etika dan keamanan yang membutuhkan perhatian khusus dan perlu untuk diregulasi. Permasalahan-permasalahan tersebut memiliki banyak bentuk, dimulai dari cyber-bullying, pemalsuan identitas, hacking dan cracking, berbagai macam perangkat lunak yang merugikan (Spyware, Adware, Ransomware, Virus, Malware, dan sebagainya), pembajakan, plagiasi, serta kebocoran dan pencurian informasi seperti halnya pada kasus Facebook (Georgescu \& Popescul, 2015).

Di sisi lain, media sosial dapat diaplikasikan ke beberapa aspek positif lain, seperti halnya pada lingkungan edukasi dengan memberikan akses dan kesempatan pelaku akademik untuk mencari dan mendapatkan sumber pengetahuan. Namun, akses ini perlu diberikan batasan dan aturan, sehingga kualitas konten tersortir dengan baik (Ali, Yaacob, Al-Amin Bin Endut, \& Langove, 2017).

Penggunaan new media, pada khususnya media sosial, untuk keperluan edukasi masih tergolong rendah. Mayoritas pengguna media sosial masih menggunakan media sosial sebagai alat untuk sekedar berinteraksi. Hal ini juga didukung oleh persepsi orang tua dimana mayoritas orang tua menganggap new media, seperti media sosial dan video game, merupakan hal-hal yang menghambat dan mengganggu aktivitas sekolah (Lim, Thanq, \& Liang, 2013). Padahal, potensi new media dalam bidang pendidikan tergolong tinggi.

\section{Komunikasi Visual Dalam Jaringan: Seni, Pesan Dan Propaganda}

Komunikasi visual merupakan salah satu bentuk komunikasi yang berfokus pada penggunaan salah satu dari panca indra, yaitu penglihatan. Komunikasi visual tidak terlepas dari proses persepsi visual yang merupakan sebuah proses untuk menentukan pengalaman dan reaksi terhadap stimuli yang dimulai dengan diterimanya stimuli yang menjadi pusat perhatian oleh indra penglihatan audiens sehingga terbentuk pengalaman sensorik yang kemudian dimaknai berdasarkan pengalaman audiens sendiri (Goldstein, 2010).

Aplikasi komunikasi visual pada new media berupa simbol visual digital. Simbol visual digital ini termasuk didalamnya gambar, foto, animasi, tipografi, dan video. Komunikasi visual dalam new media dapat disimpulkan sebagai produk multimedia berdasarkan prinsip proses gambar digital statis dan gambar digital bergerak atau audiovisual (video). Melalui proses ini, komunikator dapat mengemas banyak pesan dalam satu produk visual (Adiloglu, 2011). 


\section{National Conference of Creative Industry: \\ Sustainable Tourism Industry for Economic Development}

Universitas BundaMulia, Jakarta, 5-6 September 2018

ISSN No: 2622-7436

Persepsi visual yang dapat memberikan dampak terhadap audiens yang dibangun berdasarkan dengan komunikasi kepada audiens melalui tanda. Tanda dapat mempengaruhi dan membentuk diferensiasi makna, dimana elemen dari komunikasi visual tersebut dapat menciptakan sebuah identitas dan citra (Lukitasari, 2013). Dengan melalui komunikasi visual ini, komunikator dapat mengirimkan pesan berupa simbolsimbol kepada audiens secara tidak langsung.

Anonimitas pada jaringan internet juga mengakibatkan munculnya konten-konten yang tidak pantas. Salah satu contohnya adalah konten terorisme. Mudahnya tersebar konten-konten seperti contoh foto-foto maupun video korban bom bunuh diri terkadang membuat masyarakat resah dan malah memperkuat dampak yang diinginkan oleh pelaku teror itu sendiri, yaitu ketakutan. Dalam hal ini, literasi pengguna dalam memaknai dan mengambil tindakan sangat berpengaruh, karena apabila pengguna mengunggah atau membagikan konten-konten tersebut, itu berarti pengguna telah membantu para pelaku teror untuk mencapai tujuannya. Media massa juga memiliki peran dalam kejadian seperti ini, dimana media massa terkadang memuat pemberitaan yang justru membuat resah masyarakat (Khairil, Ali, Zakaria, Arifin, \& Razman, 2017).

Pesan visual yang mengandung unsur negatif terkadang disampaikan pula secara tidak langsung dan terkadang tersembunyi. Contohnya adalah penggunaan lambanglambang satanik dan illumiati yang dikemas dalam detail video game. Pada konteks ini, terkadang pengguna tidak menyadari bahwa pada video game yang pengguna mainkan terdapat konten-konten dan pesan-pesan satanik dan iluminati(Saputra, 2016).Contoh lain adalah pada video klip yang diunggah oleh para musisi, seperti musisi-musisi dari Korea Selatan atau yang sering disebut dengan boybanddan girlband. Beberapa video klip dari musisi-musisi kenamaan Korea Selatan mengandung simbol-simbol satanik dan illuminati(Haris, 2016).

Simbol-simbol paling sering muncul dan digunakan pada kedua contoh tersebut adalah All-SeeingEye, yang merupakan lambang dari illuminati itu sendiri.Selain AllSeeingEye, simbol-simbol lain yang sering digunakan adalah Pentagram dan Hexagramyang berhubungan langsung dengan simbol-simbol satanik. Pentagram dan Hexagram sendiri merupakan simbol-simbol yang digunakan untuk memuja dan memanggil setan pada kebudayaan barat.

Penggunaan simbol-simbol tersebut pada sebuah karya visual dapat menghasilkan beberapa pemaknaan. Simbol-simbol tersebut dapat dimaknai hanya sebagai detail penambah pada sebuah karya visual dan bukan berupa pesan utama yang hendak dikirimkan kepada komunikan, atau simbol-simbol tersebut dapat diartikan bahwa komunikator hendak memberikan pesan utama yang bernuansa satanik dan illuminati melalui karya visualnya kepada komunikan. Kembali lagi, disiniliterasi pengguna berperan penting dalam proses pemaknaan pesan-pesan yang dikirimkan oleh komunikator melalui simbol-simbol pada karya visual yang disebarluaskan pada jaringan digital.

\section{KESIMPULAN}

Penggunaan new media, terutama media sosial, meningkat pesat seiring perkembangan teknologi serta dengan mudahnya masyarakat untuk mengakses teknologi pendukung seperti perangkat seluler. Banyaknya pengguna kemudian dimanfaatkan oleh perusahaan-perusahaan untuk memasarkan dan mengiklankan produknya. Penggunaannew media, khususnya media sosial, juga memiliki bahaya dan 


\section{National Conference of Creative Industry: \\ Sustainable Tourism Industry for Economic Development}

Universitas BundaMulia, Jakarta, 5-6 September 2018

ISSN No: 2622-7436

dampak negatif seperti cyber-bullying, pemalsuan identitas, hacking dan cracking, berbagai macam perangkat lunak yang merugikan (Spyware, Adware, Ransomware, Virus, Malware, dan sebagainya), pembajakan, plagiasi, serta kebocoran dan pencurian informasiLiterasi pengguna new media juga menentukan kemampuan pemaknaan pesan oleh pengguna, karena komunikator dapat mengemas pesan yang akan dikirimkan dengan simbol-simbol visual tertentu.

\section{DAFTAR PUSTAKA}

Adiloglu, F. (2011). Visual communication: Design studio education through working the process. Procedia - Social and Behavioral Sciences, 28, 982-991. https://doi.org/10.1016/j.sbspro.2011.11.182

Al-Rahmi, W. M., \& Zeki, A. M. (2017). A model of using social media for collaborative learning to enhance learners' performance on learning. Journal of King Saud University - Computer and Information Sciences, 29(4), 526-535. https://doi.org/10.1016/j.jksuci.2016.09.002

Al-Rahmi, W., Othman, M., \& Musa, M. (2014). THe Improement of Students' Academic Performance by Using Social Media Through Collaborative learning in Malaysian Higher Education. Asian Soc. Sci., 10(8), 210-221.

Ali, M., Yaacob, R. A. I. B. R., Al-Amin Bin Endut, M. N., \& Langove, N. U. (2017). Strengthening the academic usage of social media: An exploratory study. Journal of King Saud University - Computer and Information Sciences, 29(4), 553-561. https://doi.org/10.1016/j.jksuci.2016.10.002

Ardianto, E., Komala, L., \& Karlinah, S. (2007). Komunikasi Massa: Suatu Pengantar. Bandung: Simbiosa Rekatama Media.

Constantinides, E. (2014). Foundations of Social Media Marketing. Procedia - Social and Behavioral Sciences, 148, 40-57. https://doi.org/10.1016/j.sbspro.2014.07.016

Elena, C. A. (2016). Social Media - A Strategy in Developing Customer Relationship Management. Procedia Economics and Finance, 39(November 2015), 785-790. https://doi.org/10.1016/S2212-5671(16)30266-0

Flew, T. (2008). New Media: An Introduction. Melbourne: Oxford University Press.

Georgescu, M., \& Popescul, D. (2015). Social Media - The New Paradigm of Collaboration and Communication for Business Environment. Procedia Economics and Finance, 20(2012), 277-282. https://doi.org/10.1016/S2212-5671(15)00075-1

Goldstein, E. B. (2010). Sensation and Perception. California: Wadsworth Cengage Learning.

Haris, A. (2016). Makna Simbolik Illuminati Dalam KPOP (Korean Pop) Music Video (Analisis Semiotika Charles Sanders Peirce Pada Music Video Boy Band \& Girl Band Kpop). KINESIK, 3(3).

Khairil, M., Ali, M. N., Zakaria, S. Z. S., Arifin, K., \& Razman, M. R. (2017). Mass Media Coverage on Terrorism in Order to Achieve Peace and Justice according to the World Agenda of Sustainable Development Goals (SDGs). INFORMATION, $20(7$ (A)), 4935-4940.

Kurt, H. (2015). Acritical Review to the Media which Constructed in Media Literary Course in Secondary Education. Procedia - Social and Behavioral Sciences, 174, 711-719. https://doi.org/10.1016/j.sbspro.2015.01.606

Leidner, D. E., Gonzalez, E., \& Koch, H. (2018). An affordance perspective of enterprise social media and organizational socialization. The Journal of Strategic 
Information Systems, 27(2), 117-138. https://doi.org/10.1016/j.jsis.2018.03.003

Levinson, P. (2009). New New Media. New York: Penguin Academics.

Lim, C., Thanq, V. C. Der, \& Liang, R. (2013). Singapore Youth's New Media Participation: Consuming, being, Learning and Schooling. Procedia - Social and Behavioral Sciences, 93, 727-731. https://doi.org/10.1016/j.sbspro.2013.09.270

Lukitasari, E. H. (2013). Komunikasi Visual pada Kemasan Besek Makanan oleh-oleh Khas Banyumas. Jurnal Dewa Ruci, 8(316).

Ndiayea, I. A., \& Ndiayea, B. (2014). Sociocultural Stereotypes in Media and Intercultural Communication (Africa in the Polish Media). Procedia - Social and Behavioral Sciences, 154(October), 72-76. https://doi.org/10.1016/j.sbspro.2014.10.114

Nicolas Alarcón, C., Urrutia Sepúlveda, A., Valenzuela-Fernández, L., \& Gil-Lafuente, J. (2018). Systematic mapping on social media and its relation to business. European Research on Management and Business Economics, 24(2), 104-113. https://doi.org/10.1016/j.iedeen.2018.01.002

Novak, E., Razzouk, R., \& Johnson, E. (2012). The Educational Use of Social Annotation Tools in Higher Education: a literature review. Internet High. Educ., 15(1), 39-49.

Saputra, G. B. R. (2016). Analisis Tanda dalam Muatan Canon pada Video Game The Elder Scrolls V: Skyrim. Kinesik, 3(1).

Srivastava, S. (2008). Globalisation and The Media. Australia: Deakin University.

Varghese, N., \& Rahman, N. A. A. (2014). The Practice and Effects of Corporate Media Relations in Chennai: Beyond Just Denials and Evolving? Procedia - Social and Behavioral Sciences, 155(October), 271-276. https://doi.org/10.1016/j.sbspro.2014.10.291

Weaver, I. S., Williams, H., Cioroianu, I., Williams, M., Coan, T., \& Banducci, S. (2018). Dynamic social media affiliations among UK politicians. Social Networks, 54, 132-144. https://doi.org/10.1016/j.socnet.2018.01.008

\section{BIODATA}

Dr. Muhammad Khairil, S.Ag., M.Si. lahir di Bantaeng, 23 Oktober 1979. Lulus pendidikan strata 1 pada Universitas Muhammadiyah Yogyakarta dengan fokus pada Komunikasi dan Penyiaran Islam pada tahun 2001. Pada tahun 2004 menyelesaikan studi jenjang strata 2 dengan fokus Komunikasi Massa. Pada tahun 2011 menyelesaikan studi doktoral (jenjang strata 3) di Universitas Padjadjaran Bandung dengan fokus Ilmu Komunikasi. Saat ini menjabat sebagai dosen aktif pada jenjang Strata 1 Program Studi Ilmu Komunikasi, Strata 2 Program Magister Administrasi Negara, dan Strata 3 Program Doktoral Ilmu Sosial Universitas Tadulako. Telah banyak memiliki riwayat penelitian, dimana beberapa diantaranyaterpublish di jurnal internasional bereputasi dan terindeksScopus, serta memiliki beberapa tulisan dalam bentuk buku, dengan buku terbaru berjudul Efek Media Dalam Liputan Kasus Terorisme yang terbit pada tahun 2017. 